\title{
Horea Poenar \\ (Another) Year Zero: \\ The Commons in a Posthuman Age
}

\begin{abstract}
The concept of the post-human is now taken for granted and it is part of a series of concepts (post-history, post-theory, post-politics, etc.) that pretend to better define our contemporary times. This paper investigates if - in such a context - there is any place left for the commons. In order to pursue this investigation, we meditate on the way these fashionable concepts function and we try to test the possibility and legitimacy of a few concepts that have been brushed under the carpet by the ideology of our era: act, New Man, truth, Event, etc. It is in this tension between what our epoch (and its academic and rational framework) allows us to think and the courage to open other paths that the problem of the commons proves to be fertile and instructive.
\end{abstract}

Keywords: Community; Commons; Post-human; Following; Autobiography.

\section{HOREA POENAR}

Babeş-Bolyai University, Cluj-Napoca, Romania hflpoe@gmail.com

DOI: 10.24193/cechinox.2018.34.01
So many times they erased me, so many times I disappeared, to my own burial I went, alone and crying. I made a knot in the handkerchief but I forgot afterwards that it wasn't the only time, and I kept singing.

Maria Elena Walsh, Like the Cicada

\section{The Posthuman That Therefore I}

\section{Am}

Where does autobiography begin? In a world in which post-history has been announced, post-theory has been imposed and the post-human is either celebrated or decried, this question might seem misplaced. What if however this displacement is a reference point that we need to posit in order to test the assumptions of the present? In other words, the problem of autobiography, related as it is to the entire conceptual framework of writing, identification and affirmation, may work as a relevant prism through which an image of what we currently think the subject/ human to be could emerge. We would not start with this question if the definition of 
the human had not been intricately linked with the possibility of autobiography as early as the first installment of rational thought in the work of René Descartes. Indeed, the French philosopher postulated the right to autobiography as an exception that defines the human and consequently he refused this possibility to the animal. There is no writing (or story, or discourse) of the self in the case of the animal, be it a cat, or a snail or a monkey. Such a discourse would thus be a mode of identifying the human, it would work as a sign that could even be institutionalized - in the manner of what analyses by Michel Foucault or Giorgio Agamben would find relevant in the case of the classic or modern world: the subject is dehumanized when it loses the competence or the interest in a discourse on the self. Homo sacer would be redefined as a subject without autobiography and thus something less-thanhuman, something that can be erased or included in narratives and discourses that have the right of using him (or it?) as an automaton. We have not moved far from Descartes, for he himself saw the animal as an automaton, a machine. A live mechanism, but without the sense (and the will) of self, the animal could be understood along the laws of biology or mechanics, while the human would be more accessible through the laws of writing and the movements of the cogito. We live however in different times in which the concept of the machine itself (and thus of the animal and possibly the human or the post-human) is more and more related to what could be called the semiotic machine. At least Jacques Derrida attempts to use such a name for everything that involves artificial intelligence, cybernetics and the whole family of zoo- and bio-engineering, of the genic in general. He does that in a series of Cerisy conferences from $1997^{1}$ in which the problem of the autobiography is raised in a scenario that involves the philosopher himself and an animal, not surprisingly a cat, Derrida's cat: "I maintain that autobiography has begun there. What happens to me each time that I see an animal in a room where there is a mirror." ${ }^{2}$ We will not revisit here all the implications of the mirror and obviously of the mirror stage, ${ }^{3}$ but the questions raised in this scenario have to do with the identity of the self and of the other (the other in the mirror or in the autobiographical writing, but also the possibility of the cat being an other), but also of the fellow, of the neighbor, of the (potential) community. Is there a common world that I share not only with the neighbor, but also with the cat? Isn't it here that ecology starts or should start? In Derrida's scenario the presence of the animal derails the apparently simple identification of $j e$ suis cela, but we take the opportunity to extend the derailment (or the détournement, and we promise to come back to this) to the problem of the common room or what this meeting between a subject that is not yet one (or continuously prevented from the positive affirmation of a self) and an other that remains to be thought and thus captured (or followed or allowed to emerge - and we will see that these conceptual distinctions, although fragile, are of radical importance) by a writing or a narrative. The first problem (Derrida's problem) deals with the traditional question of the image (and thus the mirror and the possibility of mirror-ing): "Where do the image and the reflecting image begin, which also refers to the identification of one's fellow being?" 
The problem that we introduce as a supplement has to do with what in Jacques Rancière's language would be a partage $d u$ sensible. ${ }^{5}$ At a closer inspection, we might find that this supplement is already present (at least as a potential thread to be followed) in Derrida's conferences. In truth (and taking advantage of the subtleties allowed by the French language), the problem of being (and thus of identification and affirmation) is continuously connected by Derrida with all the modalities of following: I am (following), I am following you. And to these two problems (although the distinction between them is - we have seen - fragile) we may add another (apparent) complication, which obliges us to return to Descartes: the problem of therefore. Far more than a simple nod to Descartes' ergo (in cogito, ergo sum), it reaffirms the relation between a (yet-to-be-written/narrated) subject and a process of thought. For Descartes, as we have already pointed out, the human is viewed as born from an exceptionalism that draws a clear distinction between himself and the animal. Derrida is well aware of the importance of this frontier and of what is dependent on it, that's why his own position is construed on it: "I shall speak from this island of exception, from its infinite coastline, starting from it and speaking of it." ${ }^{6}$ And one of the questions that he adds to the problematics of this frontier is that of the promise. The human is/could be defined as the animal that promises (in the full knowledge that a promise is always under the risk of not being fulfilled). To us this is directly linked to the problem of the commons. Indeed, a promise is always connected to an other (even if the promise is made to oneself, as autobiography already implies the promise of a narrative to or for a self) and through this the commons can be understood less as something that subjects already have in common and more as a promise of a commonality (and why not a communism) to come. Is there an autobiography of the commons? Could it be that it starts (or it indirectly emerges) from the problem of the following? "The question of following, of the persecution and seduction of the other, what/that I am (following) or who is following me."

Let us return here (as in fact Derrida does and for the moment we are following him following an other) to Martin Heidegger and his 1946 Letter on Humanism. The German philosopher starts from the fact that "humanism presupposed the most universal essence of the human being to be obvious. The human being is considered to be an animal rationale." This assumption is deconstructed inside the horizon of the philosophical thought that Heidegger already exposed in his 1927 Being and Time. The problem of what defines the human cannot be extracted or protected from the problem of the world: "it is clearly a matter of replying to the question 'What is man?' And to reply to the question 'What is Man?' one has to reply to the question 'What is world?"' We can adapt these questions to our contemporary epoch: perhaps in order to respond to the question of "what is the post-human?," the question we cannot avoid is still "what is (post) world?" If the fundamental form of symbolic identification (assuming a symbolic mandate) - is "to recognize myself as X," as in the mirror stage defined by Lacan, then the autobiography we have begun searching should mean assuming the symbolic mandate as post-human: "That's me!" But 
already in psychoanalysis "everybody needs 'an external point of identification' to know who/what he is." ${ }^{10}$ And thus we are back to the problem of an other, of the world and of the animal (Derrida's cat) in the imagined scenario of a room with a mirror. The auto-biography of man has always been linked to transformations related to the animal. In fact for Derrida, we can even imagine what lies "beyond the edge of the so-called human (...) a multiplicity of organizations of relations between living and dead." 11 Can we imagine a post-animal world? We are contemporary with "the product of figures of animality that are so new that they appear monstrous enough to call for a change of name." ${ }^{12}$ Does not the same happen to man, with all the new technologies and the ability of science nowadays to intervene in the genetic construction of the human?

We are gathering threads here with the promise to find their relevance in a possible autobiography. As Derrida puts it, "the list of what is proper to man always forms a configuration (...) it can never be limited to a single trait and it is never closed." 13 We will inquire about the ends of man and the aftermaths of what defines the post-human. We will try to see what does the post-human follow or what is his/her/its relation with the other(s)? Can promises still be made in the post-human age? Can there be a way of sharing the room (or the commons) with an other, be it an animal or a fellow? Can there be a way of sharing the vulnerability and the anguish or the anguish of the vulnerability of the end(s) of man and of the Idea(s) of the common(s)?

\section{Two Threads (To Follow)}

Dost-human is a name that humans Thave given themselves the right to give. What anxiety does it speak of? What sense of history does it pertain to? How does it affect the relation between man and community and even - and this is something that concerns us here - community and the commons? Questions also arise about what is proper. We have always thought - in the history of philosophy, in the writing of all kinds of autobiographies and thus of literature in all its meanings - that identity is related to what is proper. So what would it (still) be proper to human and/or the post-human? To history and time, to after and beyond?

We will choose two threads among the ones we have made visible so far. Two threads that work as two hypotheses and both start from what the name post-human invites us to meditate upon. The first one cannot avoid and in fact concentrates on the problem of time. The post in post-human invites to the foreground the entire problematics of what comes after, what follows. We will try a little bit later - and until then we shall have to leave this problem in suspense - to see whether inside such a framework we can still think history (general, individual, biographical, literary) in terms of events. In a world dominated by the discourse of post-history (which claims to mean the end of history), events (and ruptures, revolutions, violent breaks, etc.) have been pushed to the realm of undesirable and dangerous occurrences. There is nothing that scares more the current intelligentsia than the metaphor of years zero. Perhaps this is the best sign that the current status-quo has not managed 
to do away with events. Perhaps they are just around the corner and we have to be prepared for them. Anyway, the post in posthuman cannot avoid to raise the question of temporal distinctions, of differences which are not, cannot be systemic. If the posthuman is more than just another modernist mania of defining the stages of a history than can be revealed or gathered in the discourse of judgment, understanding or progress, then it can only be thought as something that escapes the logics of capture and as such it demands a different writing. What would an autobiography of the posthuman be, if it refuses the narrative logics that have been used for the human?

The second thread - still preoccupied with what the name post-human obliges us to think - concerns the human. What has gone wrong, given that the human is now thought in a certain past, as already a memory, with all its limits and traps? What is, if anything, (still) proper to human? Isn't the Post-human an invention needed in order to protect against the Idea of a New Man? As if technology (and thus ultimately - neoliberal - economy) would make posthumanity unavoidable (even necessary), an option thought to be less violent (although we have to interrogate what violence means in these times) than the violence of New Man, believed to arise from the necessary (again, this word, the darling of conservative historians nowadays) imposition of an Idea. We do not need to revisit here why we live in times in which Ideas are considered unwelcome and neither will we investigate how we have arrived at this point. The violence of the neoliberal system and of its ideologues cannot be underestimated, but at the same time this should not work as an excuse. The post-human seems to arise more as a scientific and economic consequence, while the New Man is viewed as imposed, a horizon that an ethical Idea needs in order to legitimize its transformation of reality. Perhaps this is due to a limited reading of Marx. According to McKenzie Wark, far from conceiving the human outside the progress of science and technology, "Marx deploys the category of the human against that of the capital through a theory of technology,"14 which is viewed as a space of possibility. Could science and technology still point today towards a new kind of species-being? Or is it that nowadays commodity fetishism is coupled with a machine fetishism? "Occult qualities are ascribed to both commodities and machines, omitting the labor that mediates them.. ${ }^{15} \mathrm{We}$ witness a leveling of the human/ animal/ machine. We even notice - in the euphoria of posthumanity which mirrors the euphoria of posthistory - a new form of valuing history and the social system: "the mark of a good society would be both the elaborated forms of humans and tech it would make, and perhaps not being able to tell them apart anymore." ${ }^{16}$ Isn't this the (not even secret) dream of technology fetishism that has invaded all fields of knowledge and activity, even the reorganization of the educational system in relation to this point of reference?

If the post-human is an aftermath of technological evolution, perhaps then - in a world that refuses to guide itself after an Idea and accepts to go with the flow (of a system that it no longer debates) - as Amy Wendling observes, following Marx, "society lays the groundwork for future human agency behind the backs of its human agents. ${ }^{17}$ This seems paradoxical, especially 
in an age that still heavily uses the liberal ideology of individualism. It is however likely that "capitalism cynicism insists we be individual subjects when actually we're dehumanized nodes in indifferent meshes of humans and nonhumans." ${ }^{18}$

It is perhaps proper here to invoke Maurizio Lazzarato's work, especially his 2014 book Signs and Machines: Capitalism and the Production of Subjectivity. His main point is that the contemporary individual is subject to a machinic enslavement. He is thus no longer a (proper) human, a rational subject in the tradition of Descartes or the subject of the Enlightenment. In the era of cognitive capitalism (which in a style of thought that refuses to think the end of history would come after the Fordist industrial capitalism) and of the biopolitics (defined by Michel Foucault and further analyzed by Giorgio Agamben), what remains of the human is caught in a web of nonhuman and inhuman apparatuses ${ }^{19}$ that - far from producing free individuals, in control of their will and subjectivities - makes dividuals emerge. As McKenzie Wark puts it, the machinic enslavement "makes desubjectivized flows and fragments. It turns those subjects into component parts of machines (slave units in the cybernetic sense). Social subjection makes subjects; machinic enslavement makes $d i-$ viduals. It divides up the self and attaches bits of it here and there to machinic processes as less-than-human agents." ${ }^{20}$ This production of dividuals makes impossible any idea of solidarity or even dialogue between rational individuals in the manner of Habermas' thought about the public sphere. It even demands a rethinking of the concepts of alienation and exploitation; in Marx, they still required the concept of the subject. But currently "capital exploits not workers but machinic assemblages, and is indifferent to their relative organic or metallic composition. All labor is cyborg labor." ${ }^{21}$ How is one - in such a context - able to resist? Through these new forms of exploitation, capitalism nowadays appropriates all commons (natural, social, ideatic). It produces the subjects it needs, it doesn't just submit them to liberal ideology. It does that mainly by its machinic control of desire.

According to Paul B. Préciado, "the body no longer inhabits disciplinary spaces but is inhabited by them." 22 The control of the subjectivity is much tighter than in the classic models exposed and analysed by Michel Foucault. There is no longer a natural body, or an essential (sense of) self: "we are not a body without organs, but rather an array of heterogeneous organs unable to be gathered under the same skin." ${ }^{23}$ The era of the social networks and of the domination of the selfe leads to a pornification of the body. Everything is exposed, just as everything is said. Under the apparent freedom of the internet, the individual does the free (unpaid) work that the corporations that rely on information and the circulation of it need. The flows to which a person adapts, the models that it mimics and the merchandise that he or she consumes work as a virtual identity that more and more fails to cover or hide the void underneath it. The posthuman's sole identity is virtual, but no longer as a response to ideological interpellation ${ }^{24}$ or as symbolic identification. The subject seems liberated from the trauma of the family and/or the archive. The uncontrolled flows of information make any archive unstable and powerless. What counts for the posthuman is a different 
form of capital: machinic, enslaved and abstract. For Préciado, "the father and mother are already dead. We are the children of Hollywood, porn, the Pill, the TV trashcan, the internet, and cyber-capitalism. The cis-girl wants to transform her body into a consumable image for the greatest number of gazes... She wants her pornification to transform her body into abstract capital." 25 There is however a downside to this (apparent) liberation of desire. In Slavoj Žižek's terms, "there is an unmistakable dimension of 'beyond the pleasure principle' in our dealings with artificial organs and gadgets: instead of enhancing our pleasures and powers, they cause fear and anxiety." ${ }^{26}$ The post-human is thus not the improvement of human, the beyond-human that would freely embrace the flows of desire. Every act of post-humanity derails the logics and narratives that used to define the human. It thus derails autobiography, it forbids it to simply follow old models of narrativity. "What makes such gadgets so uncanny is that, far from simply supplementing human organs, they introduce a logic that fundamentally differs from, and so unsettles, the 'normal' libidinal economy of sexed human beings qua beings of language." 27

So what is left? What does survive in this continuous play of post-human flows and circulations? "The post-historical human, or post-human animal, detaches form from content and no longer aims to transform the content, only the form, the simulacra." ${ }^{28}$ Biopolitics is coupled with bioeconomics and posthistory seems to announce the reign of a world bereft of any Idea. Is there an Event that could provide a running line out of this looping circuit? Is there any common ground left to gather, share and resist?

\section{Year(s) Zero and The Problem of Events}

$\prod$ he idea of the year zero was famously used in cinema by Roberto Rossellini in the title of his 1948 movie Germania Anno Zero, in which we follow the story of a German family shortly after the war, trying to survive amidst the ruins and changing face of the world. Because mainly of hunger and lack of essentials for life, the father is sick, his daughter has to entertain American soldiers and the first son is hiding due to his having been a member of SS. The younger son, Eduard, has to face the hardships at a very early age and he aims to provide for his family through any means possible (theft, black market, etc.).

However this is not an uplifting film. The Nazi ideology survives in spite of the changes and the young boy succumbs to it and poisons his father. At the end of the movie, realizing what he has done, Eduard commits suicide, by jumping from a high building. So what does the year zero name here? Is it the sign of an Event, a reshaping of the world after the fascist era? Does such a change require the sacrifice of a young boy?

Later, more precisely in 1991, JeanLuc Godard refers to Rossellini's film and to the idea of the year zero in his movie about - once again - Germany, but this time at the end of the Communist era: Allemagne année 90 neuf zéro. The story follows the character Lemmie Caution played by Eddie Constantine (whom Godard has used in his 1966 Alphaville) in his wandering through East Germany, this time among the ruins of an ideology and the world constructed in its image. The movie starts with a fallen street sign 
that used to proudly announce that one is walking on the Karl Marx Street and ends with the character entering West Germany, a world full of advertising lights, totally dedicated to the consumerist principles of capitalism and ironically balanced by the Bible offered on the table of every hotel room. Once again the question arises: what does year zero name? Is the post-communist world the product of an Event? The word revolution has often been used in the Western media to name the fall of the Berlin Wall or the changes in Eastern Europe, but Godard's movie seems to distance itself from it. There is more of a melancholy in the air: on the one hand, the Idea of communism is dead; on the other, the new world about to emerge is Idea-less. There is no Event in store: just the End of History. In the spirit of Fukuyama, the year zero doesn't name a new beginning, a new calendar or a different narrative of history, but just the end of counting. There is no revolution in the air: just the feeling that the world has given up trying.

In philosophy, the most famous author that uses the concept of the Event is of course Alain Badiou. In the field of politics, for Antonio Negri and Michael Hardt - and their 2014 Declaration - an Event names "a subjective kairos that breaks the relations of domination and overthrows the processes that reproduce the figures of subjugation." ${ }^{29}$ While for Badiou, an Event can name something that redistributes the understanding of life and of the world at the level of a subject when he steps out from his monad (like in love, which for $\mathrm{Ba}-$ diou is the minimal communism, because it requires the perception and judgment of everything from the point of view of Two, no longer of one subject), for Negri and
Hardt an Event is also possible only as a collective experience: "a singular subjectivity discovers that there is no event without a recomposition with other singularities." ${ }^{30}$ So, once again, what is the case of our non-evental times? Is there no longer any possibility of a collective experience that would overthrow the process and the system of subjugation?

What needs to be noticed here is that an Event is perceived as a breaking of an order (which suddenly, under this new light, appears old and conservative). In a world in which (almost) everything has its place, its cause and its narrative, an interruption appears that derails all the forms of understanding. What is essential is that this interruption is not just the end of an ideology (which can emerge through its own play of contradictions, or by its being defeated by the ideological enemy), but the emergence of something completely new, that requires the whole reorganization of things, including simple things like counting the years. It is no surprise that the Jacobin revolution introduced a new calendar and imagined changing all things, including forms of behavior that would lead, of course, to a new human. This emergence can only be perceived, at first, as irrational, a moment of madness, because rational thought itself has to change: "the normal flow of things is interrupted, another dimension breaks in." ${ }^{1}$ For Žižek, the remarkable thing is not how the (individual or collective) subject falls into madness and acts within it, but how from the depths of this very madness it can build an entirely new symbolic reality. That's why, in the case of an Event, "madness is constitutive." 32 A Revolution cannot name the simple move from one narrative to an already existing 
other narrative (like in the case of the anti-communist changes around 1989), but the emergence of a new narrative (or a new Idea) that first of all posits its own past (it makes its own causes visible only after it has emerged $^{33}$ ) and also produces new ways of thinking so that the simple enthusiasm of change (like in the Tahrir Square in 2011 or in the Occupy movements after 2008) is not enough for an Event: the construction of a new reality and a new set of values is also necessary. In Žižek's terms, "the ultimate act of abyssal madness is the act of imposing a rational Necessity on the pre-rational chaos of the Real." ${ }^{34}$ This is indeed frightening thinking for any conservative ideologues of current day liberalism. It means nothing less than an understanding of truth which is very different from a stable, outside-history definition: "truth is temporal and evental." 35 Truth is thus object of change. That's why any new love is the true love. And that is why revolutions are not predictable, they just emerge and redistribute the understanding of what is possible and what is impossible. Any epoch's ideology tries to present/dissimulate itself as something outside ideology and thus the only possible solution. It consequently considers different ideas as impossible. An Event is precisely what makes the impossible possible. Care should however be taken in regard to discerning an Event (or in Badiou's language a moment of truth). Was, for example, 1914 an Event? This is a question that Slavoj Žižek poses and he points out another possibility: what if the avant-garde (with its high point in 1913) was the True Event? In this reading, 1914 is to be understood as a reactionary move against the avant-garde and what this made possible. One of the arguments invoked by the Slovene philosopher is "the fact that the fascists or other patriots hated the vanguard Entartete Kunst is not a marginal detail but a key feature of fascism." ${ }^{36}$ To paraphrase here Walter Benjamin, any reactionary and conservative violence against certain ideas (or works of art or narratives of history) is a clear sign that we may have to do with an Event. As such, 1914 is not "an awakening, but the forceful and violent return of a patriotic slumber destined to block the true awakening." ${ }^{37}$ As for our times, the current violence against the idea of communism (especially in Eastern Europe and in the case of ideologues that seemed to ride with the times in the 90s and are now more and more perceived as conservatives) is proof that anti-communism is no longer a "natural" feeling, in no need of rhetorical weapons or "rational" arguments, but precisely that it needs more and more ideological help in order to appear natural. Does this however mean that the Idea of Communism $^{38}$ is (re)emerging precisely when the violence against it seems to be greater? Does it mean that an Event could become possible again? Thinking along these lines supposes the interpretation that whenever there is danger, the redemptive forces also grow. It is the old story of emancipation from the 19th century onwards, that decadent times bring the possibility of a new beginning, etc. Karl Marx himself is caught in this paradigm: "Marx's notion of historical process therefore remains fundamentally a teleological one: all history hitherto points towards the present moment, we live in kairos, the time of shift, and are able to discern in the miserable present the possibility of an act to come." 39

This leaves us with two problems. On the one hand, the post-human seems less 
like the emergence of a new truth (and thus the proof of an Event) and more and more like a reaction to the idea of New Man (even on the part of authors of the Left that have moved more and more to a centrist position, the new ideological place par excellence of our times, authors that delight themselves for example in the ridiculous collage between Emmanuel Macron and the idea of Revolution). Perhaps, the Idea of the New Man was the true Event and all the violence against it acts as an attempt to block the awakening that it makes possible. On the other hand, such an understanding of post-humanity seems to name the end (or the twilight) of any possibility of a collective experience that would produce something new (and thus, in the language used inside these pages, something true).

\section{Twilight of the Humans}

卫 he end of Richard Wagner's tetralogy (Der Ring des Nibelungen) deals with the twilight of the Gods. In the correctly famous 1976 staging of Boulez/Chéreau from Bayreuth, the direction suggests that the world is now emptied not only by Gods but also Superhumans of all kinds and what is left behind, interpellated now to imagine a new world, is the collective group of humans. The Gods are gone (of all kinds, for not only Siegmund and Brünhilde disappear in the catastrophe of the final fire, but also the lower gods, like Hagen), the (aristocratic) heroes are also gone and with them gone are the rules, the order and the myths of the past. The gold is also back in the possession of the Rhine maidens, so humanity will not be able to choose a mercantile future. The last moments of the staging portray the mass of proletarians gathering closer to the frontier that delimits the stage from the spectators as if at any moment they were ready to join in the same group. Alain $\mathrm{Ba}-$ diou points to the significance of this final image that contains the universal relevance of this production: "this ending consists in the fate of the world being handed over to generic humanity, since no specific nation is mentioned. (...) After the gods comes humanity, regarded in a revolutionary sense, an utterly generic, not specific, sense. ${ }^{\text {"40 }}$

There are however essential details that need to be observed in these last minutes of the staging. First of all, with the sacrifice of Brünhilde, the twilight of the gods is portrayed through a big fire in which she jumps. The mass of proletarians, at first terrified of the violent end and with their back to the spectators and facing the fire, retreats and most of them kneel. Only a few of them - in a marvelous choreography - remain standing. At this point they are almost in the same position as the spectators. What happens next is of utmost importance. First two women stand up and turn towards the public. As the last chords and the leitmotif of redemption through love erupt in all their force, slowly all those on stage turn and face the spectators and remain immobile, as the fire turns into smoke behind them. The music dies. The women, men and children on the stage share a perfect silence with the public. Badiou finds this moment extremely relevant, in the connection it suggests between the group of people on the stage and the audience: "the crowd of men and women on stage slowly stands up, turns to face the audience, and in essence asks: 'What about you? Here is where we stand now, you and we both.' It is an extremely powerful gesture, implying 
self-denial on the part of the conductor in not having the last word, since the image persists for quite a while after the music has ended." ${ }^{\prime 1}$ Everything seems to suggest that this is the moment that will come to be counted as year zero. The Event is not only the twilight of the Gods (albeit a necessary occurrence), but the consciousness gained by the collective who is now ready to take charge and define the commons. Everything is about to begin because of this cut (the disavowal of gods and myths) and through this gaze, which can only be characterized as an ethical injunction.

It is important to notice that the demythologization of the gods does not lead to a mythologization of the humans. The group of people on the stage (again, a relevant choreographic choice) is not ordered. This can be contrasted to the 2012 Metropolitan Opera François Girard/ Daniele Gatti staging of Parsifal which clearly addresses the Chéreau production in its opening scene: while the overture is played, we observe the group of (aristocratic) knights, all in white shirts and suits, carefully arranged in the front part of the stage facing the audience. Everything is ordered, even their gestures and the fact that Parsifal himself, even before his actual coming-to-terms with his mission and the fact of acting as the Chosen One, is part of this group powerfully reaffirms the accent on order. The knights seem to be in uniform, as if each of them, particular or individual as he might be, is only relevant through their sharing the same generic identity. In contrast, the group of women and men at the end of Chéreau's Ring is a multitude. Each keeps her or his own individuality and no generic identity is suggested. It is only through this refusal of an ordered identity that they represent an universal (never attainable through myth) entity. This multitude (again, contrary to the ordered cast of knights) is open, and for this reason the invitation addressed to the public is not one of joining an existing (within clearly defined rules and characteristics) community, but of assuming the risks and responsibilities of representing the commons. We will return to this difference. Suffice for the moment to point out that, in Badiou's reading, the Chéreau production which demythologizes Wagner (contrary to the traditional productions before him) is paralleled by Boulez's radical options of highlighting the discontinuities in Wagner's music at the cost of following the continuities (again, a traditional preference): "the Boulez-Chéreau-Regnault production was a demythologized presentation of Wagner. (...) Similarly, rather than attempting to bring out the continuity of Wagner's music, Boulez's conducting instead strove to highlight its underlying discontinuity. (...) an analytical way of conducting whose aim is to make us hear the complexity of Wagner's compositional techniques behind the flow of the music in the service of mythification." ${ }^{42}$ This demythologization and the highlight of discontinuity may suggest that the humanity at the end of the Ring is already, in the terms we have used here, a posthuman one. There is no human essence that will now replace the essentialism of gods and heroes. In a way, this is why Nietzsche was so disillusioned with Wagner's Parsifal, for he perceived there a return to a Christian and/or German identity and thus to an essence that could be portrayed in a particular identity. Alain Badiou displaces this reading of Parsifal in a courageous interpretation: "I will suggest that the subject of Parsifal is the question as to whether a 
modern ceremony is possible. The subject is the question of ceremony, and this question is intrinsic to Parsifal. It is distinct from the question of religion. Why? Because a ceremony can be said to be a collectivity's or even a community's mode of self-representation, but transcendence is not an essential condition of it." ${ }^{43}$ For the multitude, the anarchic revolt is not enough; it has to organize itself, to talk and question itself, to analyze and to produce itself. To be fair to the 2012 Met production, it can be read along these lines: the celebratory form does not require a myth that should electrify the masses, but a form of solidarity and responsibility to certain values or ideas. For this to be(come) possible, an event (like the emergence of Parsifal) must happen. And it is not a long stretch to read in Parsifal the traits of post-humanity. Again, Badiou: "Parsifal's arc goes from the powerlessness of purity's ignorance to purity as power or force, purity as force of knowledge. (...) we go from purity as non-knowledge to purity as force of knowledge." ${ }^{\prime 4}$

It is high time now that we return to Derrida and to the distinction between the animal and the human. The French philosopher is, as we have seen, on the trail of the definition of the human as a rational animal. As such, humanism has always been a rational humanism, believing in an essence of humanity that could be captured and exposed in the process of thinking. For Derrida, "this so-called 'rationalist humanism' is in a hurry to enclose and circumscribe the concept of human as much as that of reason. The deconstruction that matters to me here should also promote itself in the name of another history, another concept of history, and of the history of the human as well as that of reason." ${ }^{45}$ One such history, in its contemporary form, makes a distinction between human capitalism (retroactively constructed as a myth by liberals who are not at ease with the neoliberal twist) and post-human capitalism (often the mantra of the neoliberal ideology). Its claim is that at some point (differently pinpointed in time) the good old capitalist system was derailed into an often monstrous form that we find itself captured in. We will leave aside the scenario (most often encountered in Eastern Europe these days) that we have a good capitalism (the Western one) and a bad capitalism (the Eastern one) whose fault is that it is still too much tied to the State (too few privatizations, too much state control, etc.) We are less interested here in the imagined scenarios that could lead us back from the neoliberal capitalism to the liberal one that existed before the Chicago School's experiments that started in Chile in 1972. What is more relevant at this point is the evolution of the liberal paradigm as it has been exposed and analyzed by authors such as Michel Foucault, Giorgio Agamben or Michel de Certeau. The French historian and sociologue's 1980 The Practice of Everyday Life could help us narrate the evolution of the human into the posthuman through a transformation of juridical politics to medical politics. We have thus moved "from an apparatus of tools that mark or shape the body in the name of a law, through the body as an incarnation of knowledge to a therapeutics of extraction and addition." ${ }^{46}$ Long before the digital era and the theoretical fashion of referring to the production of the cyborg, Michel de Certeau observes that "the activity of extracting or adding is carried out by a reference to a code. ${ }^{\prime 77} \mathrm{We}$ are more and more under the control of an apparatus that Jean-Luc Godard portrayed 
in Alphaville which guides our behavior and regulates our desires. "Nothing escapes the apparatus, but the cry." ${ }^{48}$ In a behavior that later would be adapted to the digital age by Paul B. Préciado and his image of the cis-girl entering the process of pornification that transforms her into abstract capital, the system has the function to "make the body tell the code." ${ }^{49} \mathrm{It}$ is important to note here that in 1980 (when the Cold War ideology tried to portray a totalitarian communist East opposed to a liberal capitalist West), Michel de Certeau was well aware (as Agamben would point out later) that "economic individualism and totalitarianism do the same. ${ }^{50} \mathrm{In}$ fact, economic liberalism is even more successful in this posthumanization of society. Everything is made to tell the code and is reduced to the language of the commodity. "No kind of knowledge production, whether of science or culture or even philosophy, is exogenous to the commodity form anymore." ${ }^{51}$ This generalized commodification was made possible by political decisions like the advent of intellectual property which represents "a mutation in the private property form, that encloses the commons of information and spawns whole new categories of potential commodities." ${ }^{52}$ Of course, what is ironic (and this has been repeatedly exposed by studies authored by the likes of Naomi Klein, Richard Seymour or Anthony Loewenstein) is that "it takes an awful lot of communism to keep forms of private property, exploitation and accumulation afloat." ${ }^{.53}$ One such form of communism for the rich (apart from obvious example of the saving of the banks - and bankers - after the 2008 crisis through a redistribution of capital from the bottom to the top) is how capital feeds on and by reducing the commons. According to McKenzie Wark, "like natural resources such as water and air, the general level of technology is something capital gets 'free of charge' from the commons." This rape of the commons goes hand in hand with the growing "cyborg mix of human effort and inhuman apparatus." ${ }^{55}$ Not only labor, but the forms and procedures of knowledge have been modified. For example, science is able to know things from the history of the universe that preceded the emergence of humanity (a period that can thus be called nonbuman) through technological forms that - although created by humans - are capable of a perception that can only be called inbuman (like the Hubble telescope, for example). This "machinic perception alienates the human from the human, by being the inbuman register of the nonbuman." ${ }^{56}$ This register makes the definition of the human based on the distinction between rational beings and what lacks this rational ability suspect or dated. The era of the posthuman combines the inhumanity of new forms of perception with the nonhuman reign of the market. We are told again and again that the mechanism of the market should be kept apart from any intrusion or tampering, especially when they are done in the name of the commons. This however returns us to the problem of the essence of the human. Are we to understand that the posthuman names an alienation of the human from his essence? Or is there, in the name of the posthuman, an understanding that there never was a human in the sense of an essence that is now lost? And what, if any, is the space of freedom to act in all of this?

Perhaps the space of freedom emerges - as in Wagner - only in the twilight, in the subtraction. In the case of Wagner, the twilight of the Gods allows or interpellates humans to act freely. In the Chéreau/Boulez 
production, this freedom is something that needs invention and risk and the solidarity of all those that are part of the multitude. As such, it is an ethical freedom in the style of Kant (for whom freedom makes me responsible to such a degree that my very acts of freedom are in fact the realization of their necessity). For the contemporary world, the subtraction of the humans leaves a space of freedom that the post-human names without getting overexcited by it. For it is not a positive freedom, but the freedom of play allowed through the very failure to posit a human essence. "If the alienation of the subject in the symbolic order were to succeed, we would be totally integrated into that order and thereby reduced to being puppets of the big Other; what gives us space to breathe is thus the very failure of our efforts - through this failure, the subject separates itself from its symbolic representations. Since the subject does not exist outside of these representations, it is itself an effect of them, it can only gain a space of freedom through the failure of its representations. " ${ }^{\text {7 }}$ The post-human is thus not an alienated human, because "in alienation, the subject experiences the Other as the full agent running the show, as the one who 'has it' (what the subject is lacking), ${ }^{158}$ and the necessary act would consequently be the (re)capture of this it that could cover the lack. What is however essential to note here is that "there is no original unity preceding loss, what is lost is retroactively constituted through its loss, and the properly dialectical reconciliation resides in fully assuming the consequences of this retroactivity." ${ }^{59}$ The relevance of Žižek's position lies in this: we should think in terms of dis-alienation and according to the understanding that there never was a human essence that is now lost.
It is the twilight that creates the gods, in Wagner, a fact fully clear through the character of Wotan who at the beginning of the Ring is in full power but then slowly has to face and accept the decay and end of his world.

Similarly it is the twilight that creates retroactively the human. The commons are thus possible not when a community unaffected by capitalism (or a humanist capitalism prior to the inhuman or posthuman neoliberal one) could be discovered, but precisely when the community is no longer possible and thus a different way of sharing the commons has to be imagined/invented. This way, one renounces the claimed "authenticity" of an identity prior to its fall, and has to do with the faulty situation on offer. In other words, the very understanding that there is no transcendent Idea that should guide us clears the place for a communal (or communist, that is democratic - through participation, not representation) invention. This invention remains open and demands continuous scrutiny and risk. The commons understood like this are not based on consensus, but rather are traversed by what Jacques Rancière finds to be at the core of the idea of democracy (albeit not in what our current day liberal democracies pretend to be): the organization of dissensus.

\section{From Community to Commons}

W e do live in what seems to be non-evental times. The announcement of the end of history and thus of post-history has been made and it is now pretty clear that it names the desire to keep the neoliberal system as the only system possible and/or desirable. What this system names or defends has also become 
quite clear in the last years (at least since 2008). According to McKenzie Wark, "the very terms of public debate are set in advance by what is in the interests of the entrepreneurs. ${ }^{60}$ Decisions on the common are taken by private interests and the commons are continuously privatized. At a global level, systems of health and education, for example, are passing into the hands of the capital representatives and ideologues. Decisions on ecology, genetics, economics, etc. are increasingly taken or influenced by so-called experts, lobbyists, think-tanks funded by corporations and mass-media is heavily controlled by money. There are also enough "new philosophers" 1 (some of them willingly) ready to legitimize all this status-quo and especially to protect against the possibility of changing it. What should be done, in such a situation, is for McKenzie Wark "to imagine a kind of common hacker class interest among those whose efforts end up being commodified as some sort of intellectual property: artists, scientists, engineers, even humanist and social science academics." ${ }^{62}$ But this is obviously easier said than done. We live, in the opinion of Negri and Hardt, according to the figure of the mediatized, who is not passive or active, but rather constantly absorbed in attention and suffocated by dead information. The key to relating the mediatized to the commons is not in the quantity of information that one could gather or face, but in "the construction of political affects, which requires a physical proximity." ${ }^{63}$ The two authors consider that a struggle for the common is urgent, one that contests the injustices of the system and ultimately the rule of private property. Through physical proximity - visible for example in the different forms of Occupy movements from the last decade that have many times functioned as a kind of happening, as in contemporary art ${ }^{64}-$ political affects and a new common sense could be created. These should work, for Negri and Hardt, as the foundational principles for a new politics, one that is no longer captured in the representative model of democracy. The commons cannot be politically active through representation, as communities can (up to a point and that limit is not our concern here), because representative politics has proven repeatedly to be, by definition, "a mechanism that separates the population from power." ${ }^{65}$ On the other hand, the "dominant media creates obstacles to every emergent form of democratic participation." ${ }^{66}$ It is no surprise that this is happening, as the media is controlled by capital, but it has become clear that "democracy will be realized only when a subject capable of grasping and enacting it has emerged." ${ }^{67}$

For a participatory democracy to emerge, the focus should not be on communities (for they are always liable to be closed, filtering access to themselves through different characteristics of race, religion, class, etc. and thus being prone to different forms of fascism), but on the commons, which here names what is common beyond any particular feature and what must be kept open for anybody anywhere, especially those that systems exclude or marginalize. For this to happen, communication is important for it might achieve what Negri and Hardt name a "making ourselves while being together - collective self-production. ${ }^{" 68}$ It is however doubtful that the internet and the social networks are able to let such a collective production emerge: "iterative loops of communication have not really led to a realization 
of democratic ideals of access, inclusion, participation. On the contrary, ours is an era of capture, of desire caught in a net and reduced to mere drive." ${ }^{69}$ Communicative action, especially the one made possible through the frameworks of social networks, is not necessarily enlightenment. The mechanism of a social network is based not on reading and interpreting signs and messages and thus finding and producing forms of dialogue, but on the simple circulation of signs. The idea is not to read, but like and share. The circulation of signs is in tune with the circulation of capital and the possibility of capturing everything, every bit of life and private area in the grasp of the market. The present, according to McKenzie Wark is "where accelerated capital blocks the formation of community; where the cell phone makes possible endless recombinations of fragments of labor, making all of time potentially productive." 70 No area is or will be outside the grasp of capital. The work one does through the circulation of signs (that leads to the collection of data, the profiling of potential customers, the functioning of ideology, etc.) is obviously unpaid and it appears under the guise of individual freedom, even as a form of good life. But "the market is not there to enable the good life; all of life is to be sacrificed to keeping the market going." 71 In such a (post-human) context, the solution imagined by McKenzie Wark, an author that constantly returns to the example of the Situationists, is to be imagined through the strategy of détournement. Just as the trickster for Michel de Certeau is the one that makes do with what is available in order to get something out of the system that (ab)uses him or her (and just as for Jean-Paul Sartre it's important what one does with what others have done of him or her), "détournement is precisely the tactic of treating all information as the commons, and refusing all private property in this domain." 72 For Negri and Hardt, this would be a form of (stubborn) resistance whose time has arrived or which is urgently required. "There is a kairos of resistance as well as a kairos of community"73 and the current crisis of capitalism - or the different forms it has taken - have made possible a being together in which a new politics could emerge, especially if we understand politics in Judith Butler's terms as something that emerges between bodies. Such a politics creates communities, it does not represent already existing ones. In this latter case politics would be just a form of protecting the interests of a particular community defined through certain characteristics and most likely limiting access to itself through certain filters (race, class, etc.). A politics that creates (always-open) communities - which would thus be impossible to manipulate or be captured by fascism - can only be based on an ethics of the commons, emerging - again - between bodies and "based on the reciprocal recognition of the social debts we owe to one another and to society"74. These two forms of politics can be defined through the opposition that Jacques Rancière makes between police-politics and emancipatory-politics ${ }^{75}$ or, in the language of Negri and Hardt, a politics based on the ethics of the commons would be "a destituent rather than a constituent process - an exodus from the existing political structures." ${ }^{76}$ In $D e c-$ laration, the two authors specify the means of such an exodus: essentially, there must be a break out of the representative system; then - as certain post-Occupy movements 
have repeatedly asserted - there must be a refusal to pay debt (such an option has a real chance to destroy the system of money) and a decision to break our attention from the media by becoming invisible and thus free, through desertion and disobedience. All these steps will produce new subjectivities (based on the commons) and thus the politics and community that they make possible have a chance to be open to universality.

Can the post-human be universal or does it remain a mechanism of generalization (a particular situation or identity that is globally generalized)? Is the post-human the new subaltern and if so (if this hypothesis can be followed for a moment), does it have a voice? For Alexander Galloway, in Gaming: Essays on Algorithmic Culture, the answer to Gayatri Spivak's questions about the subaltern is: "the subaltern speaks and somewhere an algorithm listens." 77 Post-humanity can thus be described as a closed loop between the less-than-human of the subaltern or the musselman (nowadays more and more illustrated by the figure of the refugee, the sans-papier, etc.) and the technological and economic system that allows all possible flows but no lines of flight. A line of flight can only be the result of a work, one that is conscious of its importance and of its engagement, a work that is done by what Negri and Hardt name the commoner: "Commoners are not just common for the fact that they work but, rather and more important, because they work on the common. We need to understand the term commoner, in other words, as we do the designations of other occupations, such as baker, weaver and miller. Just as a baker bakes, a weaver weaves, and a miller mills, so, too, a commoner commons, that is, makes the common." ${ }^{" 78}$ The engagement of the commoner is what makes the leap from the generic (post)human - the subject produced by the ideological and economic system - to the universal subject which is always defined only in relation with the others. As Žižek repeatedly asserts, "the only way to arrive at true universality is by way of a reasoning that is sustained by a practical engagement." ${ }^{79}$ For Negri and Hardt, "becoming singular, in contrast to becoming individual, means finding once again the subjective force in a being together." ${ }^{\prime 00}$ This represents in the understanding of the subject (and of the human) a paradigm shift and a leap from the individual to the collective in order to become an autonomous and participatory political subject. This decision must be both singular and common. It is a matter of what "can be constitutionalized as common" ${ }^{\prime 1}$ and what can be transformed into institutions of the common. This is again a difference (let us call it a vectorial one, for it focuses on the invention of a community through politics, not on a politics that protects a particular community) that has to deal with how the private can be identified with respect to the public and especially how what is public could be transformed into common. The public sphere is not immediately common, as Jürgen Habermas thought, because it is still too much controlled by private interests or, in the case of real-existing communism, it was something that blocked the participatory democracy necessary in order for the existence of the commons as a political object.

An invention must follow. It could be, for Negri and Hardt, "a new dispositif that is based in a radical asymmetrical standpoint. This standpoint is elsewhere even 
when it shares the same space." ${ }^{\prime 2}$ Alain Badiou himself refers to a different understanding of time. The post-human, starting with the name it was given, is subject through a very rigid conception of time, one that paradoxically pretends that it only follows, it never opens, because there is nothing, no Event left to open or break or cut. The post-human is what follows a human that is retroactively constructed, a human that has never existed and this is obvious, as in Derrida's scenario, every time we are in the same room with a mirror and a cat. For Alain Badiou, the responsibility of the commoner is to think according to a different time ${ }^{83}$ that is not the one imposed on him, one that exists as a reference that can rearrange the distribution of what is possible and what is impossible. If the post-human (as is the case with the entire fad of the last decade to post everything; post-history, post-modern, post-theory, etc.) really names what prevents invention, what makes the new man obsolete or utopian or simply post-possible, invention becomes a political act. One upon which the commoner falls, one she cannot not do. And the formulation here is essential: it is not a matter of what the commoner can or could do, but of what she cannot not do. This is where ethics begins.

\section{The Law of the Symptom}

I nside the first pages of The Animal That Therefore I Am, where he begins describing the scene between himself and the cat, Jacques Derrida points out that there is another meaning of the word "symptom" that is not usually taken into consideration: the fact that it "also means 'fall': case, unfortunate event, coincidence, what falls due, mishap." ${ }^{84}$ The explanation comes inside a parenthesis that itself falls at a very important moment. The image of the cat facing the naked subject is being described and the mirror has not yet entered the scene, as it will do very quickly in order to derail this facing or better facingness ${ }^{85}$ that captures everything in a loop. In a way and to a certain extent, the mirror will tame what is difficult to grasp in this scene, something that shouldn't in fact take place if the frames of rational thought, the definitions invoked for what is human and what is not and what is animal and what is cat are at hand in order to guide us through what is happening. For something indeed does happen. "Something happens there that shouldn't take place - like everything that happens in the end, a lapsus, a fall, a failing, a fault, a symptom." ${ }^{86}$ The mirror will introduce - as it always does - the problem of representation and that of identity, of the mirror stage and of the theatrics always involved when we deal with presence and meaning and with that it introduces the predictable scene of madness and of the Cheshire Cat, during the discussion on the meaning of words and of the word "word": "we're all mad here.I'm mad. You're mad." 87 The moment of madness, to return to the scene prior to the introduction of the mirror, is the scene of an intersection of gazes and specifically of the gaze of the other, in this case a cat and not Alice's cat. What it does is disturbing: "the gaze called 'animal' offers to my sight the abyssal limit of the human: the inhuman or the ahuman, the ends of man, that is to say, the border crossing from which vantage man dares to announce himself to himself, thereby calling himself by the name that he believes he gives himself." ${ }^{\prime 8}$ All philosophers in search 
of the definition and essence of the human - and this neglection is what brings them together - refuse to take into consideration this gaze, as if it never happened (or never fell) to them. It is here that Derrida finds a telling symptom: "the symptom of this disavowal could not be the figure of just one disavowal among others. It institutes what is proper to man, the relation to itself of a humanity that is above all anxious about, and jealous of, what is proper to it." ${ }^{19}$ What is neglected is the happening that shouldn't take place as is in fact the case with everything that happens. To put it differently: the possibility of something happening is related to its being outside a framework or a horizon of expectations. In other words, an Event. And the gaze of the cat is an event because it concerns thinking (which only happens as an event, it cannot be predictable): "the animal looks at us, and we are naked before it. Thinking perhaps begins here." ${ }^{90}$

A little further in his book, in a passage that analyses briefly Freud's presumption that woman is more naturally modest than man, Derrida exposes the law of the symptom: "modesty or shame is, naturally, such an aporetic movement, so self-contradictorily, so exhibitionist within its very logic, that the most modest will always also be - this is the law of the symptom - the least modest." "11 It falls (due). As - and we will not be surprised that this takes place in a Derridean text - philosophy does. In the passage that we will cite, it concerns Heidegger and his belief in a concept like Nur-Lebenden (the mere life, life in its pure state, something that would define the animal as opposed to the human who is more-than-mere-life) as in something that could thus be the legitimizing origin not only of a system of thought, but of a way of behaving that permits for example the whole genocide of animals that has closely and shamefully (and thus, according to the law of the symptom, with much exhibited pride and arrogance) represented the companion history to the history of man, that history "that the man tells himself, the history of the philosophical animal" ${ }^{2}$ to which pure philosophy is the symptom of. A concept, then, or a pseudo-concept, "this fiction, this simulacrum, this myth, this legend, this phantasm, which is offered as a pure concept." ${ }^{93}$ We are of course aware that later, for authors like Giorgio Agamben, this mere life names the bomo sacer, that frontier that is no longer clearly defined between human and less-than-human, for homo sacer occupies it. No longer strictly alive, but not yet dead, it very much names a living specter, something that is undead, but not living. And history - which always requires a witness, one that however is not a mirror that represents something that exists outside and prior to it, but something like the musselman that Primo Levi considers to be the right witness for the Holocaust - begins here. In its (already) act of falling (due).

If the concept of human has only ever been retroactively posited, a phantasm offered at times as a pure concept, and the autobiography of man has always functioned as the becoming-history of a fiction, in a way we have always been post-human. What is important is to understand that post here doesn't name a temporal sequence, something that would come after, but that gap that is inherent to any fiction, that does not allow it to have or be present. There are thus no pure concepts which in a way liberalism and postmodernism 
have quickly understood. There is an entire vocabulary of concepts that post-history has brushed under the carpet. The mechanism that allowed this selection is clearly ideological, but there is a catch. Slavoj Żižek proves that "one of the lessons of the critique of ideology is that it is not only knowledge that is socially constructed but also ignorance. ${ }^{" 4}$ We have to pay attention, in relation to liberal ideology, to the subtle way through which things are unlearned. It is a tactic that has allowed, for example, important figures of the radical Left - who were openly or indirectly communists - to be tamed and thus transformed into liberal icons. Martin Luther King or Nelson Mandela come immediately to mind. One forgets that the name of Mandela was erased from the CIA list of dangerous individuals only after 2000 and one carefully selects what to cite from the works of Martin Luther King. The same process of unlearning has transformed a figure like Winston Churchill into a liberal hero. In fact, in most cases, the pantheon of liberalism has been carefully cleansed as Domenico Losurdo has shown in Liberalism. A Counter-History.

What is important in this context is also the constant unlearning in discussions on post-humanism of the socio-economic factor. Here, especially in relation to the problem of the subject, of the human and its history or autobiography, the work of Maurizio Lazzarato proves relevant. In Signs and Machines, he diagnoses a contemporary crisis of subjectivity. We are caught in a machinic enslavement through which, as McKenzie Wark puts it, capitalism "launches new subjectivities like new model iPhones, only these days the subjectivities are all basically just bloatware versions of the same model." ${ }^{95}$ And he continues on capitalism: "all it offers is just debt servitude and lottery tickets. Contrary to the slogans repeated over and over, there's not much 'innovative' or 'creative' about it." 96 The problem is not to recover an original, true subjectivity, for "even if there were some original or primordial human nature to be expressed, there is no reason to believe it would foster free, equal and democratic social and political relations. ${ }^{\prime 97}$ This is a key point: even if there were a human essence and it proved to be - as liberal thinking repeatedly implies - selfish and violent, we should still orient ourselves according to a different one, even with the acceptance that it is fictional, that it is a creation. It is in this sense that we have to read Negri and Hardt's injunction "to make new truths." 98 For them, one such created truth is to be found in the slogan invented by the Occupy movements after 2009 that positions the $99 \%$ against the $1 \%$. This works as a truth ${ }^{99}$ that cuts through reality and demands an ethical act. It is important to note here that it is the law of the symptom that prevents such an act from presenting itself as natural or objective. Žižek observes that "every act is by definition too early and simultaneously too late (...) there is no right moment to act - if we wait for the right moment, the act is reduced to an occurrence in the order of being." 100 An act, a truly political act, can only occur and manifest itself as a symptom. It is not produced as an effect by causes that could be detected in the state of things. Those causes are always retroactively posited. An act has to be an invention and thus one has to accept the risks that come with every invention. On the one hand, this means a detachment - or even an escape - from the order and logic imposed on us. 
"The guardians keep the floodgates - as they see them - closed to questioning. We have to learn to pose our own questions. And refuse the answers when the questions to which they answer are answers for nobody, for whoever, rather than answers for us." ${ }^{101}$ On the other hand, an act always implies the other. Because an act is free (it is not made necessary by the logic of the system - that's why in fact the liberal system is not a system of freedom, for it carefully protects against acts and inventions in the name of the state of things that should not be disturbed or to which all responsibility is transposed: it is the market that decides, not us), it is always a sign and an occurrence of the common: for Negri and Hardt, we should focus on "the collective construction of freedom, because freedom is not individual, it is always an effect of the way commons are structured and protected."102

Once more we will return here to the law of the symptom. Maurice Blanchot defined literature as the manner of speaking that speaks through manner, ${ }^{103}$ which is why literature is not just a discipline or a form of discourse among others, but, still being a particular discipline, it is the only one that is open to universality (all the others have access to generalization). There is no original form of discourse, just like there is no language that is or would be the root of all the others. However, we have to posit this gap (between such a root language and the concrete ones) in order for languages to exist. This gap is always inherent to literary invention, for it can be said that the literary act always identifies with the symptom. For Žižek, "to identify with a symptom means to recognize in the excesses, in the disruptions of the normal way of things, the key offering us access to its true functioning." ${ }^{104}$ It is in this sense that literature is at the same time the essence of the truth (in Lacanese, the real that they can never reduce to the symbolic constructions that define their functioning) of all the other disciplines and a discipline among the others. Can we then imagine a literary political act? We do not mean this just in the sense - and it is Jacques Rancière's sense in Politique de la littérature - that all literature (and art) is always political through its very specific mechanisms, but in the sense of an act that would give access to universality and not generalization (and simultaneously an act that produces the commons without the need of a closed community). Such a political act is defined by Susan Buck-Morrs in her Hegel, Haiti, and Universal History: "human universality emerges in the historical event at the point of rupture. It is in the discontinuities of history that people whose culture has been strained to the breaking point give expression to a humanity that goes beyond cultural limits. ${ }^{105}$ A people - while remaining singular, a singularity revealed at breaking point, in the fissures and discontinuities of history - gives expression to universality through this double act: it exposes and condemns the true functioning of a system that leads to exclusion, inequality and continuous privatization of the commons, and it lets another possibility emerge, one that follows this exposure. It is inside such a horizon that the idea of the year zero (and with it the concept of New Man, etc.) becomes possible and desirable, with the acceptance that there will not be (and there shouldn't be) a single year zero. It is an idea that Hegel and Marx accepted and it is at this point or juncture that a (literary) political act could emerge. 
And so we can return - one final time - to the problem of following. The commons are always something that follows, just as autobiography is always caught (and only thus possible) in the act of following. But this should be understood symptomatically, in the opening of what the Zapatista model of the commons succinctly puts it: to lead by following and to walk forward questioning. ${ }^{106}$ On December 21, 2012, the day when the Mayans had predicted that the calendar and thus the world would end, the Zapatista movement re-emerged to the attention of the world through a mass silent protest in Chiapas, Mexico. According to the Western media, more than 40,000 people walked in the rain, covered with masks, with discipline and dignity, and at the end of the demonstration a short text, a written communiqué, was read by Subcomandante Insurgente Marcos: "Did you hear it? It is the sound of your world crumbling. It is the sound of our world resurging. The day that was day, was night. And night shall be the day that will be day."
We can conclude with this literary political act. The world indeed survived the announced ending. The expected apocalypse (which was probably expected along the Hollywood imaginary as total destruction) did not happen. But what if the Zapatista march was the true Event? Just as the narrator of Marcel Proust's novel knew so well, the real travelling is done by changing the eyes of perception. There was no world crumbling, and yet the sound of it indeed crumbling could be heard (and this is again the law of the symptom at work). A Year Zero was announced. There will no doubt be others. No commons can be caught in the single narrative of any calendar, not even the post-anything one. As with everything that (really) happens, as with thinking and as with following through leading, years zero should not exist. And yet they do, to the shock and fury of ideologues and historians ${ }^{107}$ everywhere. And to answer that fury, we can - once again - let the Zapatistas speak: "We are sorry for the inconvenience, but this is a revolution."

\section{Works Cited}

Althusser, Louis, Essays on Ideology, London and New York, Verso, 1993

Badiou, Alain, Five Lessons on Wagner, with an afterword by Slavoj Žižek, London and New York, Verso, 2010

Badiou, Alain, The Meaning of Sarkozy, translated by David Fernbach, London and New York, Verso, 2010

Blanchot, Maurice, The Book to Come, translated by Charlotte Mandell, Stanford, CA, Stanford University Press, 2003

Buck-Morss, Susan, Hegel, Haiti and Universal History, Pittsburgh, University of Pittsburgh Press, 2009

Carroll, Lewis, Through the Looking Glass in The Complete Works of Lewis Carroll, New York, Modern Library, 1936

Chomsky, Noam, Profit over People: Neoliberalism and Global Order, New York, Seven Stories Press, 1998

de Certeau, Michel, The Practice of Everyday Life, translated by Steven Rendall, Berkeley, University of California Press, 1984 
Derrida, Jacques, The Animal That Therefore I Am, edited by Marie-Louise Mallet, New York, Fordham University Press, 2008

Douzinas, Costas and Slavoj Žižek (eds.), The Idea of Communism, London, Verso, 2010

Fried, Michael, Manet's Modernism, Chicago and London, University of Chicago Press, 1996

Galloway, Alexander R., Gaming: Essays on Algorithmic Culture, Minneapolis, University of Minnesota Press, 2006

Lacan, Jacques, Écrits, translated by Bruce Fink, New York, Norton \& Company, 2006

Lazzarato, Maurizio, Signs and Machines: Capitalism and the Production of Subjectivity, Los Angeles, Semiotext(e), 2014

McKee, Yates, Strike Art. Contemporary Art and the Post-Occupy Condition, London and New York, Verso, 2016

Negri, Antonio, Michael Hardt, Declaration, New York, Argo Navis, 2012

Poenar, Horea, Teoria peștelui-fantomă. Zece studii și șapte scurt-metraje despre teorie, București, Tracus Arte, 2016

Préciado, Paul B., Testo Junkie: Sex, Drugs, and Biopolitics in the Pharmacopornographic Era, The Feminist Press at the City University of New York, 2013

Rancière, Jacques, Le partage du sensible: esthétique et politique, Paris, La Fabrique, 2000

Rancière, Jacques, Les mots de l'histoire. Essai du poétique du savoir, Paris, Éditions du Seuil, 1992 Rancière, Jacques, On the Shores of Politics, translated by Liz Heron, London, Verso, 2007

Rancière, Jacques, The Politics of Aesthetics. The Distribution of the Sensible, London, Bloomsbury, 2014

Wark, McKenzie, General Intellects. Twenty-one Thinkers for the Twenty-First Century, New York, Verso, 2017

Wendling, Amy, Karl Marx on Technology and Alienation, Basingstoke and New York, Palgrave Macmillan, 2009

Žižek, Slavoj, Absolute Recoil: Towards a Nerw Foundation of Dialectical Materialism, London, Verso, 2014

Žižek, Slavoj, The Sublime Object of Ideology, London and New York, Verso, 1989

\section{Notes}

1. Published in Jacques Derrida, The Animal That Therefore I Am, edited by Marie-Louise Mallet, New York, Fordham University Press, 2008.

2. Ibidem, p. 58.

3. For details, see Jacques Lacan, "The Mirror Stage as Formative of the I Function as Revealed in Psychoanalytic Experience," in Écrits, translated by Bruce Fink, New York, Norton \& Company, 2006. 4. Jacques Derrida, The Animal that Therefore I Am, p. 59.

5. See Jacques Rancière, Le partage du sensible: esthétique et politique, Paris, La Fabrique, 2000. The English translation of the term is "distribution of the sensible," in Jacques Rancière, The Politics of Aesthetics. The Distribution of the Sensible, London, Bloomsbury, 2014.

6. Jacques Derrida, The Animal That Therefore I Am, p. 62.

7. Ibidem, p. 65.

8. Martin Heidegger, Letter on Humanism, apud Jacques Derrida, The Animal That Therefore I Am, p. 71.

9. Ibidem, p. 145 .

10. Slavoj Žižek, Absolute Recoil: Towards a New Foundation of Dialectical Materialism, London, Verso, 2014, p. 289. 
11. Jacques Derrida, The Animal That Therefore I Am, p. 31 .

12. Ibidem, p. 80.

13. Ibidem, p. 5.

14. McKenzie Wark, General Intellects. Twenty-one Thinkers for the Twenty-First Century, New York, Verso, 2017, p. 17.

15. Ibidem, p. 19.

16. Ibidem, p. 26.

17. Amy Wendling, Karl Marx on Technology and Alienation, Basingstoke and New York, Palgrave Macmillan, 2009, p. 135.

18. McKenzie Wark, General Intellects, p. 78.

19. "The nonbuman enters human history through the inbuman mediation of a technics where labor deploys it," in ibidem, p. 249.

20. Ibidem, p. 79.

21. Ibidem, p. 80.

22. Paul B. Préciado, Testo Junkie: Sex, Drugs, and Biopolitics in the Pharmacopornographic Era, The Feminist Press at the City University of New York, 2013, p. 79.

23. Ibidem, p.116.

24. See Louis Althusser, Essays on Ideology, London and New York, Verso, 1993.

25. Paul B. Préciado, Testo Junkie, p. 408.

26. Slavoj Žižek, Absolute Recoil, p. 277.

27. Ibidem, 280.

28. McKenzie Wark, General Intellects, p. 212.

29. Antonio Negri, Michael Hardt, Declaration, New York, Argo Navis, 2012, p. 27.

30. Ibidem, p. 28.

31. Slavoj Žižek, Absolute Recoil,p. 182.

32. Ibidem, p. 185.

33. This is why the historiographic model emerging after François Furet is simply wrong: one cannot understand the Event of the French Revolution by studying the narratives existing before it (and thus imagining that 1789 or 1792 emerged as a direct cause of something already existing previously), but by understanding the new perspective on pre-1789 that only the Event itself made possible. There is here a war between two ideas of History: one that thinks that there are no (or there should not be) Events, because history either has its slow non-violent course or that its course is a false impression (and ultimately there is no history in the sense of a narrative that guides or leads the world) and one that considers Events as breaking points that retroactively change the understanding of the past. This is also true for the history of art or any dimension of thought.

34. Slavoj Žižek, Absolute Recoil, p. 185.

35. Ibidem, p. 187.

36. Ibidem, p. 158.

37. Ibidem.

38. We understand this Idea in the light of the philosophical discussions available in The Idea of Communism, edited by Costas Douzinas and Slavoj Zižek, London, Verso, 2010.

39. Slavoj Žižek, Absolute Recoil, p. 346.

40. Alain Badiou, Five Lessons on Wagner, with an afterword by Slavoj Žižek, London and New York, Verso, 2010, p. 101.

41. Ibidem, p. 105.

42. Ibidem, p. 6.

43. Ibidem, p. 147.

44. Ibidem, p. 140.

45. Jacques Derrida, The Animal That Therefore I Am, p. 105.

46. Michel de Certeau, The Practice of Everyday Life, translated by Steven Rendall, Berkeley, University of California Press, 1984, p. 142. 
47. Ibidem, p. 147.

48. Ibidem.

49. Ibidem.

50. Ibidem, p. 148.

51. McKenzie Wark, General Intellects, p. 13.

52. Ibidem, p. 10.

53. Ibidem, p. 51.

54. Ibidem, p. 25.

55. Ibidem, p. 272.

56. Ibidem, p. 288.

57. Slavoj Żižek, Absolute Recoil,pp. 330-331.

58. Ibidem, p. 347.

59. Ibidem.

60. McKenzie Wark, General Intellects, p. 304.

61. At origin it names a group of former Maoists French intellectuals that deserted the emancipatory ideas in the 70s to form what has become known as the antitotalitarian thought which accepted the neoliberal system and legitimized it in the name of human rights. They were portrayed by Gilles Deleuze as "buffoons" and Alain Badiou considers that their ideas represent a form of "reactionary humanism." Not surprisingly, they became the darlings of the media and after 1990 the key authors invoked by the anti-communist ideology in Eastern Europe.

62. McKenzie Wark, General Intellects, p. 11.

63. Antonio Negri, Michael Hardt, Declaration, p. 17.

64. This dimension of the emancipatory movement after 1990 has been extensively analyzed by Yates McKee in Strike Art. Contemporary Art and the Post-Occupy Condition, London and New York, Verso, 2016.

65. Antonio Negri, Michael Hardt, Declaration, p. 24.

66. Ibidem, p. 23.

67. Ibidem, p. 26.

68. Ibidem, p. 31.

69. McKenzie Wark, General Intellects, p. 146.

70. Ibidem, p. 100.

71. Ibidem, p. 180.

72. Ibidem, p. 157.

73. Antonio Negri and Michael Hardt, Declaration, p. 28.

74. Ibidem, p. 30.

75. See Jacques Rancière, On the Shores of Politics, translated by Liz Heron, London, Verso, 2007.

76. Antonio Negri and Michael Hardt, Declaration, p. 39.

77. Alexander R. Galloway, Gaming: Essays on Algorithmic Culture, Minneapolis, University of Minnesota Press, 2006, p. 137.

78. Antonio Negri and Michael Hardt, Declaration, p. 83.

79. Slavoj Žižek, Absolute Recoil, p. 229.

80. Antonio Negri and Michael Hardt, Declaration, p. 28.

81. Ibidem, p. 56.

82. Ibidem, p. 44.

83. In The Meaning of Sarkozy, translated by David Fernbach, London and New York, Verso, 2010, p. 35, Alain Badiou considers that we should "construct, in the temporality of opinion, a different duration." 84. Jacques Derrida, The Animal That Therefore I Am, p. 4.

85. This is of course the concept of Michael Fried from Manet's Modernism, Chicago and London, University of Chicago Press, 1996 through which it proves the modernity of Manet's paintings.

86. Jacques Derrida, The Animal That Therefore I Am, p. 4. 
87. Lewis Carroll, Through the Looking Glass in The Complete Works of Lewis Carroll, New York, Modern Library, 1936, p. 72.

88. Jacques Derrida, The Animal That Therefore I Am, p. 12.

89. Ibidem, p. 14.

90. Ibidem, p. 29.

91. Ibidem, p. 57.

92. Ibidem, p. 22.

93. Ibidem.

94. Slavoj Žižek, Absolute Recoil,p. 209.

95. Maurizio Lazzarato, Signs and Machines: Capitalism and the Production of Subjectivity, Los Angeles, Semiotext(e), 2014, p. 77.

96. Ibidem.

97. Antonio Negri and Michael Hardt, Declaration, p. 38.

98. Ibidem, p. 31.

99. A similar truth was created in Romania during the street protests against the planned privatizations of gold resources in the Apuseni Mountains. The protesters repeatedly claimed that all political parties were equally corrupt and thus understood that the current representational system was not able to offer solutions. Unfortunately this truth was lost several years later when, during the street protests of 2016 and 2017, the street succumbed again to an understanding of politics along party lines.

100. Slavoj Žižek, Absolute Recoil,p. 191.

101. McKenzie Wark, General Intellects, p. 309.

102. Antonio Negri and Michael Hardt, Declaration, p. 37.

103. I resume in this paragraph one of the key points of my book Teoria pestelui-fantomă. Zece studii și șapte scurt-metraje despre teorie, București, Tracus Arte, 2016. For Blanchot's definition, see Maurice Blanchot, The Book to Come, translated by Charlotte Mandell, Stanford, CA, Stanford University Press, 2003.

104. Slavoj Žižek, The Sublime Object of Ideology, London and New York, Verso, 1989, p. 144.

105. Susan Buck-Morss, Hegel, Haiti and Universal History, Pittsburgh, University of Pittsburgh Press, 2009, p. 133.

106. This political model is discussed in Noam Chomsky, Profit over People: Neoliberalism and Global Order, New York, Seven Stories Press, 1998 and Antonio Negri, Michael Hardt, Declaration, p. 34.

107. We are referring here to Jacques Rancière's portrayal of historians in Les mots de l'bistoire. Essai du poétique du savoir, Paris, Éditions du Seuil, 1992. 